\title{
Azospirillum formosense sp. nov., a diazotroph from agricultural soil
}

\author{
Shih-Yao Lin, ${ }^{1}$ Fo-Ting Shen, ${ }^{1}$ Li-Sen Young, ${ }^{2}$ Zhi-Long Zhu, ${ }^{1}$ \\ Wen-Ming $\mathrm{Chen}^{3}$ and Chiu-Chung Young ${ }^{1}$
}

Correspondence Chiu-Chung Young ccyoung@mail.nchu.edu.tw
The genus Azospirillum originally comprised two species, namely Azospirillum lipoferum and Azospirillum brasilense, when it was first created with the reclassification of 'Spirillum lipoferum', a root-associated nitrogen-fixing vibrioid bacterium with single polar flagella (Tarrand et al., 1978). Until now, a total of 14 species has been described: A. lipoferum (Tarrand et al., 1978), A. brasilense (Helsel et al., 2006), A. amazonense (Falk et al., 1985), A. canadense (Mehnaz et al., 2007a), A. doebereinerae (Eckert et al., 2001), A. halopraeferens (Reinhold et al., 1987), A. irakense (Khammas et al., 1989), A. largimobile (Ben Dekhil et al., 1997), A. melinis (Peng et al., 2006), A. oryzae (Xie \&

The GenBank/EMBL/DDBJ accession numbers for the $16 \mathrm{~S}$ rRNA and nifH gene sequences of strain $\mathrm{CC}-\mathrm{Nfb}-7^{\top}$ are GU256444 and HM193519, respectively.

Two supplementary figures and a supplementary table are available with the online version of this paper.
Yokota, 2005), A. picis (Lin et al., 2009), A. rugosum (Young et al., 2008), A. thiophilum (Lavrinenko et al., 2010) and A. zeae (Mehnaz et al., 2007b). Members of the genus are widely distributed in environments such as soils of tropical, subtropical and temperate regions, where they are frequently associated with grasses, cereals and crops (Bally et al., 1983; Döbereiner \& Day, 1976; Kirchhof et al., 1997; Ladha et al., 1987; Patriquin et al., 1983). A. picis and A. rugosum were isolated from oil-contaminated soil and discarded road tar, respectively, and A. thiophilum was isolated from a sulfide spring.

The genus Azospirillum is widely known as containing freeliving nitrogen-fixing plant-growth-promoting rhizobacteria (Okon \& Vanderleyden, 1997; Okon \& Itzigsohn, 1992), and belongs to the Gram-negative alphaproteobacteria. The versatile $\mathrm{C}$ - and $\mathrm{N}$-metabolism in this genus makes it well adapted to the rhizosphere and successfully competitive 
in this environment (Steenhoudt \& Vanderleyden, 2000). Members of the versatile genus Azospirillum are known as biofertilizers and are commonly used in field tests (Steenhoudt \& Vanderleyden, 2000) because of their ability to produce plant hormones such as abscisic acid, ethylene, gibberellic acid, indole 3-acetic acid (Bashan et al., 2004) and zeatin (Tien et al., 1979) and plant growth regulatory substances such as polyamines (Thuler et al., 2003) and siderophores (Saxena et al., 1986), and to generate osmotic stress responses in plants (Aziz et al., 1997) and solubilize phosphate (Seshadri et al., 2000).

Strain CC-Nfb- $7^{\mathrm{T}}$ was isolated from agricultural soil in Yunlin County, Taiwan, on nitrogen-free broth (NFB) agar (Reinhold et al., 1987). The isolate was subsequently cultivated on nutrient agar (NA; Hi-Media) and R2A agar (Oxoid) to determine its morphological and phenotypic characteristics. Strain CC-Nfb- $7^{\mathrm{T}}$ was able to grow at 20 $37{ }^{\circ} \mathrm{C}$ and at $\mathrm{pH}$ 5.0-9.0 on these media. Growth with 0 $5 \% \mathrm{NaCl}$ was determined in nutrient broth (NB). Gramstaining was performed as described by Murray et al. (1994). The phenotypic and biochemical characteristics were investigated using the API ZYM, API $20 \mathrm{E}$ and API 20 NE systems (bioMérieux) and carbon source utilization was investigated using the Biolog GN II and API $50 \mathrm{CH}$ systems. Physiological tests were performed according to Lin et al. (2009). The morphology of negatively stained cells was determined by transmission electron microscopy. For thin sections, cells were prefixed with $2 \%$ (v/v) glutaraldehyde and $3 \%$ paraformaldehyde in $0.1 \mathrm{M}$ sodium phosphate buffer ( $\mathrm{pH} 7.2)$ for $2 \mathrm{~h}$ at room temperature and then washed three times in the same buffer. Strain CC-Nfb- $7^{\mathrm{T}}$ grew aerobically on NA and R2A agar and formed rough, light-pink (NA) or white (R2A agar) colonies after $24 \mathrm{~h}$ at $37^{\circ} \mathrm{C}$. Cells were Gramnegative, spiral or slightly curved rods, which were motile by means of a single polar flagellum. Cells contained poly$\beta$-hydroxybutyrate granules after 5 days of growth (Fig. 1).

To assay nitrogen-fixing capability, the acetylene-reduction assay was used, as described by Hardy et al. (1973). Vials

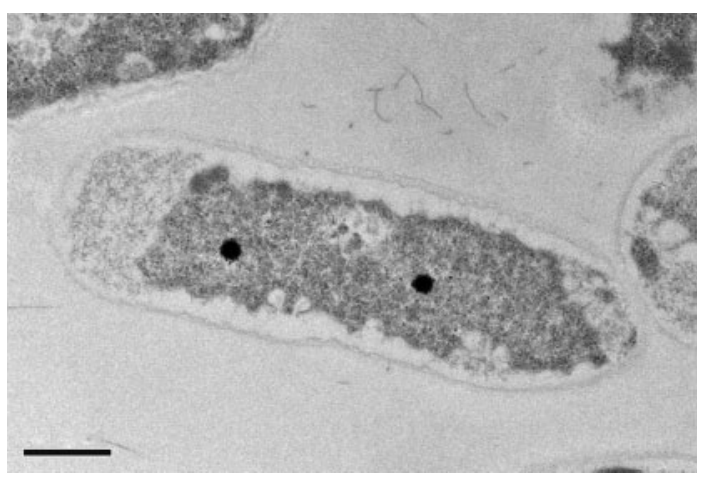

Fig. 1. Transmission electron micrograph of a cell of strain CC-Nfb- $7^{\top}$. Bar, $0.5 \mu \mathrm{m}$.
(30 ml) containing $10 \mathrm{ml}$ semi-solid NFB medium were inoculated with CC-Nfb-7 ${ }^{\mathrm{T}}$, sealed with rubber septa and incubated at $30{ }^{\circ} \mathrm{C}$ in the dark. After $72 \mathrm{~h}, 10 \%(\mathrm{v} / \mathrm{v})$ of the air phase was replaced with acetylene (Koch \& Evans, 1966) and the vials were incubated. The amount of ethylene produced in $24 \mathrm{~h}$ was measured using a FID GC (model 163; Hitachi) equipped with a flame-ionization detector and a packed column $(1.0 \mathrm{~m} \times 2.0 \mathrm{~mm}$ i.d., steel column packed with Porapak-T 80-100). The conditions of analysis were as follows: carrier gas, nitrogen; flow rate, $35 \mathrm{ml} \mathrm{h}^{-1}$; temperature of the flame-ionization detector, $110{ }^{\circ} \mathrm{C}$; column temperature, $80{ }^{\circ} \mathrm{C}$. The isolate $\left(10^{8}\right.$ cells $)$ was able to reduce acetylene to ethylene at a mean rate of $25 \mathrm{nmol}$ ethylene $\mathrm{h}^{-1}$ at $30{ }^{\circ} \mathrm{C}$, which is similar to the nitrogen-fixing activities of $A$. picis IMMIB TAR- $3^{\mathrm{T}}$ (Lin et al., 2009) and A. rugosum IMMIB AFH- $6^{\mathrm{T}}$ (Young et al., 2008) (93 and $18 \mathrm{nmol}$ ethylene $\mathrm{h}^{-1}$, respectively).

Bacterial genomic DNA was isolated using an UltraClean Microbial Genomic DNA Isolation kit (MO BIO), according to the manufacturer's instructions. The $16 \mathrm{~S}$ rRNA gene was amplified using the bacterial universal primers $1 \mathrm{~F}\left(5^{\prime}\right.$ GAGTTTGATCATGGCTCAGA-3') and 9R (5'-AAGGAGGTGATCCAACCGCA- $\left.3^{\prime}\right)$. The amplification products were about $1500 \mathrm{bp}$ long (Hung et al., 2005). Sequencing reactions were performed using a BigDye Terminator kit (Heiner et al., 1998) and the sequence was determined using an automatic DNA sequencer (ABI PRISM 310; Applied Biosystems) (Watts \& MacBeath, 2001). 16S rRNA gene sequences of members of the genus Azospirillum were obtained from GenBank and recorded in FASTA format using ReadSeq software (http://searchlauncher.bcm.tmc.edu/ seq-util/readseq.html). Sequence comparison and analysis was carried out using CLUSTAL x version 1.83 (Thompson et al., 1997) and phylogenetic analysis was performed using MEGA4 (Tamura et al., 2007). Sequence similarities and phylogenetic distances ( $K_{\text {nuc }}$ values) were determined according to Kimura (1980) and evolutionary trees were inferred using maximum parsimony (Fitch, 1971), neighbour joining (Saitou \& Nei, 1987) and maximum-likelihood (Felsenstein, 1981). An evolutionary distance matrix was calculated using the correction of Jukes \& Cantor (1969). The topology of the neighbour-joining tree was evaluated by bootstrap analysis (Felsenstein, 1985) with 1000 resamplings. Strain CC-Nfb- $7^{\mathrm{T}}$ exhibited highest $16 \mathrm{~S}$ rRNA gene sequence similarity with A. brasilense DSM $1690^{\mathrm{T}}$ (97.4\%), A. rugosum IMMIB AFH-6 ${ }^{\mathrm{T}}(96.8 \%)$ and A. oryzae JCM $21588^{\mathrm{T}}$ (96.6\%); all other members of the genus Azospirillum showed lower levels of similarity $(<96.5 \%)$. Sequence divergence of $\geqslant 3 \%$ is considered to be strong evidence that bacteria are not related at the species level (Stackebrandt \& Goebel, 1994). The neighbour-joining phylogenetic tree based on 16S rRNA gene sequences is shown in Fig. 2.

The nifH sequence was obtained by PCR using the primer set PolF (5'-TGCGAYCCSAARGCBGACTC-3') and PolR (5'-ATSGCCATCATYNTCRCCGGA- $3^{\prime}$ ) and the conditions described by Poly et al. (2001). The expected size of the product was about $360 \mathrm{bp}$. Strain CC-Nfb- $7^{\mathrm{T}}$ exhibited 


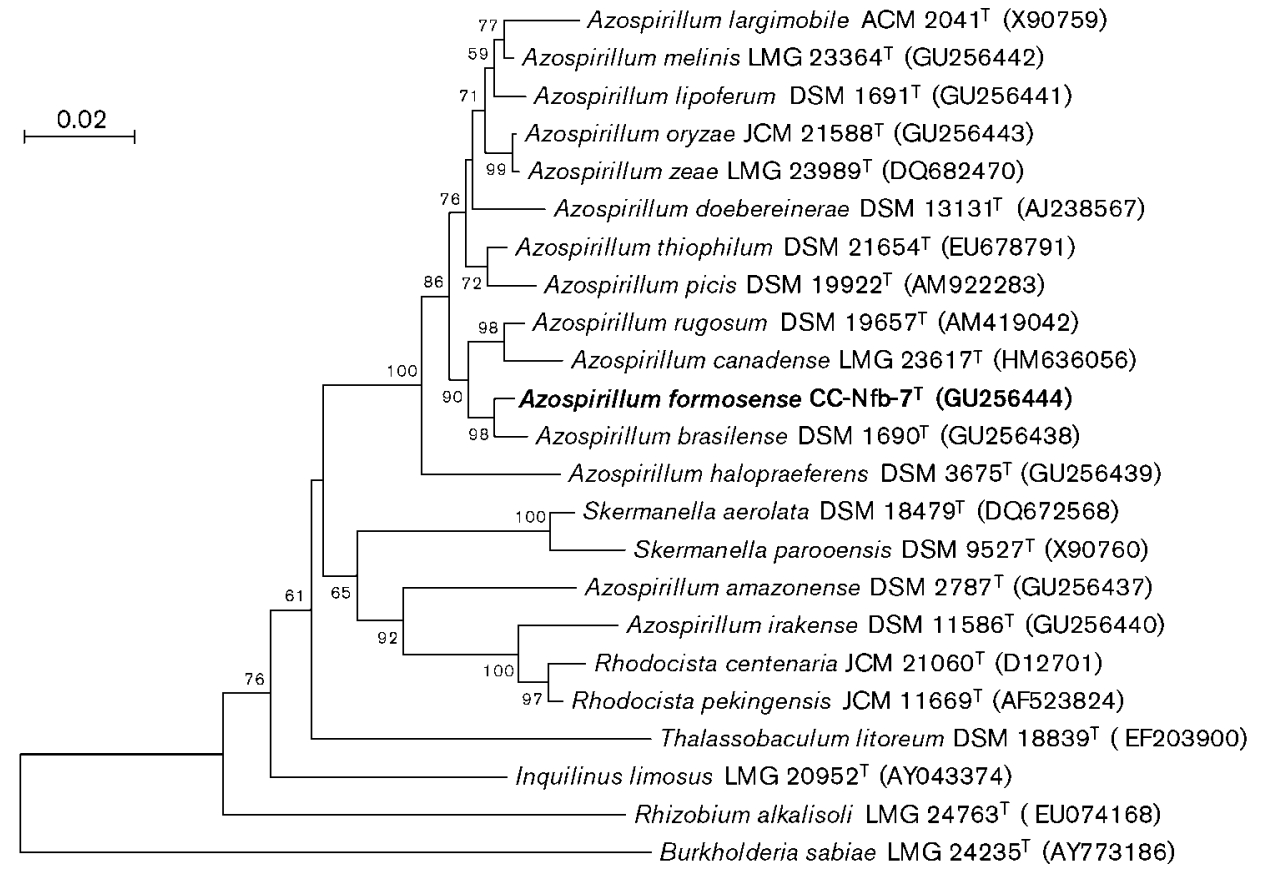

Fig. 2. Neighbour-joining phylogenetic analysis based on $16 \mathrm{~S}$ rRNA gene sequences, showing the position of strain $\mathrm{CC}-\mathrm{Nfb}-7^{\top}$ in the genus Azospirillum. Bootstrap values $>50 \%$ based on 1000 replications are shown at branch nodes. Bar, 0.02 substitutions per nucleotide position.

highest nifH sequence similarities with A. lipoferum DSM $1691^{\mathrm{T}}(95.4 \%)$, A. brasilense sp. $7^{\mathrm{T}}(94.8 \%)$ and A. oryzae JCM $21588^{\mathrm{T}}(93.9 \%)$. The neighbour-joining phylogenetic analysis based on nifH sequences (Fig. S1, available in IJSEM Online) also revealed that strain CC-Nfb- $7^{\mathrm{T}}$ belonged to the genus Azospirillum.

DNA-DNA hybridization was performed using reagents from Roche Diagnostics, according to the manufacturer's instructions. Briefly, chromosomal DNA of A. brasilense DSM $1690^{\mathrm{T}}$ was used to construct hybridization probes by labelling with digoxigenin-11-dUTP. DNA samples from strain CC-Nfb- $7^{\mathrm{T}}$, A. rugosum DSM $19657^{\mathrm{T}}$ and A. oryzae JCM $21588^{\mathrm{T}}$ were loaded onto positively charged membranes as described by Seldin \& Dubnau (1985). Prehybridization and hybridization conditions for the labelled probes were used according to manufacturer's instructions for the DIG DNA Labeling and Detection kit. After hybridization, the blots were subjected to stringent washing and the chemiluminescence detection kit based on CPD STAR was used. DNA-DNA relatedness was determined by scanning the X-ray membranes and determining the intensities using the UVP Vision Acquisition and Analysis Software version 6.8 (BioSpectrumR imaging system). Self-hybridization values were considered to represent $100 \%$ of the maximum achievable signal and values obtained with the other strains were compared with this standard. Hybridization was carried out in triplicate for each sample. DNA-DNA relatedness between strain
CC-Nfb- $7^{\mathrm{T}}$ and A. brasilense DSM $1690^{\mathrm{T}}$, A. rugosum DSM $19657^{\mathrm{T}}$ and A. oryzae JCM $21588^{\mathrm{T}}$ was $38.9,30.1$ and $31.8 \%$, respectively.

For analysis of DNA G $+\mathrm{C}$ content, DNA was prepared and degraded enzymically into nucleosides as described by Mesbah et al. (1989). The nucleoside mixture was then separated by HPLC. The DNA G+C content of strain CC-Nfb- $7^{\mathrm{T}}$ was $65.5 \pm 0.6 \mathrm{~mol} \%$. For analysis of the fatty acids, strain CC-Nfb-7 ${ }^{\mathrm{T}}$ and its closest phylogenetic neighbours were grown on NA for $72 \mathrm{~h}$ at $30{ }^{\circ} \mathrm{C}$ and harvested by scraping. Fatty acid methyl esters were prepared, separated and identified according to the standard protocol of the Microbial Identification system (MIDI) (Sasser, 1990) using an Agilent 7890A GC fitted with a flameionization detector and the Aerobe (RTSBA6) database. The fatty acid composition of strain CC-Nfb- $7^{\mathrm{T}}$ was similar to those of recognized members of the genus Azospirillum. The major fatty acids in strain CC-Nfb- $7^{\mathrm{T}}$ were summed feature 8 (consisting of $\mathrm{C}_{18: 1} \omega 7 c$ and/or $\mathrm{C}_{18: 1} \omega 6 c ; 56.4 \%$ ), summed feature 3 (consisting of $\mathrm{C}_{16: 1} \omega 7 c$ and/or $\mathrm{C}_{16: 1} \omega 6 c$; $15.1 \%$ ), summed feature 2 (consisting of $\mathrm{C}_{14: 0} 3-\mathrm{OH}$ and/ or iso- $\left.\mathrm{C}_{16: 1} \mathrm{I} ; 5.8 \%\right), \mathrm{C}_{18: 1} 2-\mathrm{OH}(6.9 \%), \mathrm{C}_{16: 0}(4.4 \%)$ and $\mathrm{C}_{16: 0} 3-\mathrm{OH}(4.2 \%)$ (Table S1). For strain CC-Nfb- ${ }^{\mathrm{T}}$, polar lipids were extracted and analysed by two-dimensional TLC according to Minnikin et al. (1984) and isoprenoid quinones were purified by the methods outlined in Minnikin et al. (1984) and analysed by HPLC as described by Collins (1985). The predominant quinone system was 
ubiquinone (Q-10). The major lipids in strain $\mathrm{CC}-\mathrm{Nfb}-7^{\mathrm{T}}$ were phosphatidylcholine, phosphatidylglycerol and one unidentified phospholipid. Furthermore, moderate amounts of phosphatidyldimethylethanolamine, phosphatidylethanolamine and one unidentified aminophospholipid were also determined (Fig. S2).

The physiological characteristics that differentiate strain CC-Nfb- $7^{\mathrm{T}}$ from other members of the genus Azospirillum are given in Table 1. The carbon source utilization pattern of strain CC-Nfb- $7^{\mathrm{T}}$ is given in the species description. Most members of the genus Azospirillum were positive for utilization of L-arabinose, glycerol and D-fructose, but negative for utilization of sucrose, L-rhamnose, maltose and lactose. Strain CC-Nfb-7 ${ }^{\mathrm{T}}$ utilized D-galactose and D-glucose, but A. brasilense DSM $1690^{\mathrm{T}}$ and A. rugosum DSM $19657^{\mathrm{T}}$ did not. With API $20 \mathrm{NE}$, strain CC-Nfb-7 ${ }^{\mathrm{T}}$, A. brasilense DSM $1690^{\mathrm{T}}$, A. rugosum DSM $19657^{\mathrm{T}}$ and A. oryzae JCM $21588^{\mathrm{T}}$ reduced nitrate and nitrite, but strain CC-Nfb- $7^{\mathrm{T}}$ did not produce urease. Strain CC-Nfb- $7^{\mathrm{T}}$, A. brasilense DSM $1690^{\mathrm{T}}$ and A. oryzae JCM $21588^{\mathrm{T}}$ assimilated L-arabinose, but A. rugosum DSM $19657^{\mathrm{T}}$ did not. Strain CC-Nfb- $7^{\mathrm{T}}$, A. brasilense DSM $1690^{\mathrm{T}}$ and $A$. oryzae JCM $21588^{\mathrm{T}}$ produced $\beta$-glucosidase and $\beta$-galactosidase and assimilated potassium gluconate and malic acid.
On the basis of morphological, chemotaxonomic and physiological data, strain CC-Nfb- $7^{\mathrm{T}}$ represents a novel species in the genus Azospirillum, for which the name Azospirillum formosense sp. nov. is proposed.

\section{Description of Azospirillum formosense sp. nov.}

Azospirillum formosense (for.mo.sen'se. N.L. neut. adj. formosense pertaining to Formosa, Taiwan).

Cells are Gram-negative, spiral or slightly curved rods $(2.5 \times 0.8 \mu \mathrm{m})$. Motile via a single polar flagellum. Oxidaseand catalase-positive. Pink colonies form after $48-72 \mathrm{~h}$, which become wrinkled and dry with time. Cells can grow on nitrogen-free medium, NB and R2A agar. Grows at 20$37{ }^{\circ} \mathrm{C}$ (optimum $30{ }^{\circ} \mathrm{C}$ ), at pH 5.0-9.0 (optimum pH 7.0) and with $0-2 \%(\mathrm{w} / \mathrm{v}) \mathrm{NaCl}$. Positive for nitrogen fixation $\left(25 \mathrm{nmol}\right.$ ethylene $\mathrm{h}^{-1}$ ). Biotin is not necessary for growth. With Biolog GN II, the following carbon sources are utilized: Tweens 40 and 80, L-arabinose, D-fructose, Dgalactose, $\alpha$-D-glucose, D-psicose, pyruvic acid methyl ester, cis-aconitic acid, D-galacturonic acid, D-gluconic acid, $\alpha$ and $\beta$-hydroxybutyric acids, $\alpha$-ketoglutaric acid, DL-lactic acid, succinic acid, bromosuccinic acid, glucuronamide, Lalaninamide, D-alanine, L-glutamic acid, L-leucine, L-proline, L-serine and glycerol. With API $50 \mathrm{CH}$, positive for assimilation of glycerol, L-arabinose, D-xylose, D-fructose,

Table 1. Physiological differences between strain $\mathrm{CC}-\mathrm{Nfb}-7^{\top}$ and its relatives within the genus Azospirillum

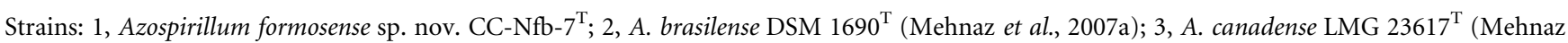
et al., 2007a,b); 4, A. doebereinerae DSM 13131 ${ }^{\mathrm{T}}$ (Eckert et al., 2001); 5, A. halopraeferens DSM 3675 ${ }^{\mathrm{T}}$ (Reinhold et al., 1987; Mehnaz et al., 2007a); 6,

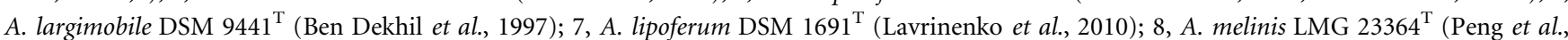
2006); 9, A. oryzae JCM $21588^{\mathrm{T}}$ (Mehnaz et al., 2007b); 10, A. picis DSM 19922 ${ }^{\mathrm{T}}$ (Lin et al., 2009); 11, A. rugosum DSM 19657 ${ }^{\mathrm{T}}$ (Young et al., 2008); 12, A. thiophilum DSM 21654 ${ }^{\mathrm{T}}$ (Lavrinenko et al., 2010); 13, A. zeae LMG 23989 ${ }^{\mathrm{T}}$ (Mehnaz et al., 2007b; Mehnaz \& Lazarovits, 2006). Data in parentheses were taken from this study. None of the strains utilized sucrose. +, Positive; -, negative; ND, no data available.

\begin{tabular}{|c|c|c|c|c|c|c|c|c|c|c|c|c|c|}
\hline Characteristic & 1 & 2 & 3 & 4 & 5 & 6 & 7 & 8 & 9 & 10 & 11 & 12 & 13 \\
\hline Polymorphic cells & - & - & ND & + & + & + & + & $\mathrm{ND}$ & ND & ND & $\mathrm{ND}(+)$ & + & ND \\
\hline Growth with $3 \% \mathrm{NaCl}$ & - & - & - & - & + & - & - & + & - & - & - & + & - \\
\hline $\mathrm{pH}$ range & $5.0-9.0$ & $6.0-8.0$ & $5.0-7.0$ & $6.0-7.0$ & $6.8-8.0$ & $\mathrm{ND}$ & $5.7-6.8$ & $4.0-8.0$ & $6.0-7.0$ & $6.5-9.0$ & ND & $6.5-8.5$ & $5.0-7.0$ \\
\hline Temperature optimum $\left({ }^{\circ} \mathrm{C}\right)$ & 30 & 37 & $25-30$ & 30 & 41 & 28 & 37 & $20-33$ & 30 & 37 & $22-37$ & 37 & 30 \\
\hline Nitrate reduction & + & $+(+)$ & + & - & - & - & + & + & $+(+)$ & + & + & + & + \\
\hline Urease & - & $+(+)$ & - & + & + & ND & - & ND & $+(+)$ & + & + & - & + \\
\hline \multicolumn{14}{|l|}{ Carbon sources } \\
\hline L-Arabinose & + & $+(+)$ & - & + & + & + & + & + & $+(+)$ & - & $-(-)$ & + & + \\
\hline D-Galactose & + & $-(-)$ & - & + & - & + & + & + & $+(+)$ & + & $-(-)$ & + & + \\
\hline D-Glucose & + & $-(-)$ & - & - & - & + & + & + & $+(+)$ & + & $-(-)$ & + & + \\
\hline Glycerol & + & $+(+)$ & - & + & + & + & + & + & $+(+)$ & + & $+(-)$ & + & + \\
\hline D-Mannitol & - & $-(-)$ & - & + & + & + & + & + & $-(-)$ & + & $-(-)$ & + & + \\
\hline D-Sorbitol & - & $-(-)$ & - & + & - & + & + & + & $-(-)$ & + & $-(-)$ & + & + \\
\hline D-Fructose & + & $+(+)$ & - & + & + & + & + & + & $+(+)$ & + & $+(+)$ & + & + \\
\hline L-Rhamnose & - & $-(-)$ & - & - & ND & - & - & + & $-(-)$ & - & $-(-)$ & - & - \\
\hline Maltose & - & $-(-)$ & - & - & ND & - & - & + & $-(-)$ & + & $-(-)$ & + & - \\
\hline Lactose & - & $-(-)$ & - & - & ND & - & - & + & $-(-)$ & - & $-(-)$ & - & - \\
\hline Biotin requirement & - & $-(-)$ & - & - & $+(-)$ & - & $+(-)$ & - & $+(-)$ & - & $\mathrm{ND}(-)$ & - & - \\
\hline $\begin{array}{l}\text { DNA G + C content } \\
(\mathrm{mol} \%)\end{array}$ & $64-66$ & $69-71$ & 67.9 & 70.7 & $68-70$ & 70 & $69-70$ & 68.7 & 66.8 & 68.7 & ND & 67 & 67.6 \\
\hline
\end{tabular}


aesculin ferric citrate, D-fucose and potassium gluconate. With API ZYM, positive for alkaline phosphatase, esterase (C4), esterase lipase (C8), leucine arylamidase, acid phosphatase, naphthol-AS-BI-phosphohydrolase and $\beta$ glucosidase. Reduces nitrate and nitrite. Produces acid phosphatase, $\beta$-glucosidase and $\beta$-galactosidase, but not DNase. The fatty acids are mainly straight-chain saturated and unsaturated fatty acids: the major fatty acid (>50\%) is summed feature 8 (consisting of $\mathrm{C}_{18: 1} \omega 7 c$ and/or $\left.\mathrm{C}_{18: 1} \omega 6 c\right)$ and the major hydroxyl fatty acids are $\mathrm{C}_{16: 0} 3$ $\mathrm{OH}$ and $\mathrm{C}_{18: 0}$ 2-OH. The polar lipids are phosphatidylglycerol, phosphatidylcholine, an unknown phospholipid, phosphatidylethanolamine, phosphatidyldimethylethanolamine and an unknown aminolipid. The predominant quinone system is ubiquinone (Q-10).

The type strain is CC-Nfb- $7^{\mathrm{T}}\left(=\mathrm{BCRC} \quad 80273^{\mathrm{T}}=\mathrm{JCM}\right.$ $17639^{\mathrm{T}}=\mathrm{DSM} 24137^{\mathrm{T}}$ ), a diazotroph isolated from agricultural soil in Yunlin County, Taiwan. The DNA G+C content of the type strain is $65.5 \pm 0.6 \mathrm{~mol} \%$.

\section{Acknowledgements}

This research work was kindly supported by the National Science Council, the Council of Agriculture, Executive Yuan and in part by the Ministry of Education, Taiwan, ROC under the ATU plan. We also thank Wei-An Lai \& Mei-Hua Hung for technical assistance.

\section{References}

Aziz, A., Martin-Tanguy, J. \& Larher, F. (1997). Plasticity of polyamine metabolism associated with high osmotic stress in rape leaf discs and with ethylene treatment. Plant Growth Regul 21, 153-163.

Bally, R., Thomas-Bauzon, D., Heulin, T., Balandreau, J., Richard, C. \& De Ley, J. (1983). Determination of the most frequent $\mathrm{N}_{2}$-fixing bacteria in a rice rhizosphere. Can J Microbiol 29, 881-887.

Bashan, Y., Holguin, G. \& de-Bashan, L. E. (2004). Azospirillumplant relationships: physiological, molecular, agricultural, and environmental advances (1997-2003). Can J Microbiol 50, 521-577.

Ben Dekhil, S., Cahill, M., Stackebrandt, E. \& Sly, L. I. (1997). Transfer of Conglomeromonas largomobilis subsp. largomobilis to the genus Azospirillum as Azospirillum largomobile comb. nov., and elevation of Conglomeromonas largomobilis subsp. parooensis to the new type species of Conglomeromonas, Conglomeromonas parooensis sp. nov. Syst Appl Microbiol 20, 72-77.

Collins, M. D. (1985). Isoprenoid quinone analysis in classification and identification. In Chemical Methods in Bacterial Systematics, pp. 267-287. Edited by M. Goodfellow \& D. E. Minnikin. London: Academic Press.

Döbereiner, J. \& Day, J. M. (1976). Associative symbioses in tropical grasses: characterization of microorganisms and dinitrogen-fixing sites. In Proceedings of the First International Symposium on $\mathrm{N}_{2}$ Fixation, pp. 518-538. Edited by W. E. Newton \& C. J. Nyman. Pullman: Washington State University Press.

Eckert, B., Weber, O. B., Kirchhof, G., Halbritter, A., Stoffels, M. \& Hartmann, A. (2001). Azospirillum doebereinerae sp. nov., a nitrogenfixing bacterium associated with the $\mathrm{C}_{4}$-grass Miscanthus. Int J Syst Evol Microbiol 51, 17-26.

Falk, E. C., Döbereiner, J., Johnson, J. L. \& Krieg, N. R. (1985). Deoxyribonucleic acid homology of Azospirillum amazonense
Magalhães et al. 1984 and emendation of the description of the genus Azospirillum. Int J Syst Bacteriol 35, 117-118.

Felsenstein, J. (1981). Evolutionary trees from DNA sequences: a maximum likelihood approach. $J$ Mol Evol 17, 368-376.

Felsenstein, J. (1985). Confidence limits on phylogenies: an approach using the bootstrap. Evolution 39, 783-791.

Fitch, W. M. (1971). Toward defining the course of evolution: minimum change for a specific tree topology. Syst Zool 20, 406-416.

Hardy, R., Burns, R. C. \& Holsten, R. D. (1973). Application of the acetylene-ethylene assay for measurement of nitrogen fixation. Soil Biol Biochem 5, 47-81.

Heiner, C. R., Hunkapiller, K. L., Chen, S. M., Glass, J. I. \& Chen, E. Y. (1998). Sequencing multimegabase-template DNA with BigDye terminator chemistry. Genome Res 8, 557-561.

Helsel, L. O., Hollis, D. G., Steigerwalt, A. G. \& Levett, P. N. (2006). Reclassification of Roseomonas fauriae Rihs et al. 1998 as a later heterotypic synonym of Azospirillum brasilense Tarrand et al. 1979. Int J Syst Evol Microbiol 56, 2753-2755.

Hung, M.-H., Bhagwath, A. A., Shen, F.-T., Devasya, R. P. \& Young, C.-C. (2005). Indigenous rhizobia associated with native shrubby legumes in Taiwan. Pedobiologia (Jena) 49, 577-584.

Jukes, T. H. \& Cantor, C. R. (1969). Evolution of protein molecules. In Mammalian Protein Metabolism, vol. 3, pp. 21-132. Edited by $\mathrm{H}$. N. Munro. New York: Academic Press.

Khammas, K. M., Ageron, E., Grimont, P. A. D. \& Kaiser, P. (1989). Azospirillum irakense sp. nov., a nitrogen-fixing bacterium associated with rice roots and rhizosphere soil. Res Microbiol 140, 679-693.

Kimura, M. (1980). A simple method for estimating evolutionary rates of base substitutions through comparative studies of nucleotide sequences. J Mol Evol 16, 111-120.

Kirchhof, G., Reis, V. M., Baldan, J. I., Eckert, B., Döbereiner, J. \& Hartmann, A. (1997). Occurrence, physiological and molecular analysis of endophytic diazotrophic bacteria in gramineous energy plants. Plant Soil 194, 45-55.

Koch, B. \& Evans, H. J. (1966). Reduction of acetylene to ethylene by soybean root nodules. Plant Physiol 41, 1748-1750.

Ladha, J. K., So, R. B. \& Watanabe, I. (1987). Composition of Azospirillum species associated with wetland rice plants grown in different soils. Plant Soil 102, 127-129.

Lavrinenko, K., Chernousova, E., Gridneva, E., Dubinina, G., Akimov, V., Kuever, J., Lysenko, A. \& Grabovich, M. (2010). Azospirillum thiophilum sp. nov., a diazotrophic bacterium isolated from a sulfide spring. Int J Syst Evol Microbiol 60, 2832-2837.

Lin, S.-Y., Young, C.-C., Hupfer, H., Siering, C., Arun, A. B., Chen, W.-M., Lai, W.-A., Shen, F.-T., Rekha, P. D. \& Yassin, A. F. (2009). Azospirillum picis sp. nov., isolated from discarded tar. Int J Syst Evol Microbiol 59, 761-765.

Mehnaz, S. \& Lazarovits, G. (2006). Inoculation effects of Pseudomonas putida, Gluconacetobacter azotocaptans and Azospirillum lipoferum on corn plant growth under green house conditions. Microb Ecol 51, 326-335.

Mehnaz, S., Weselowski, B. \& Lazarovits, G. (2007a). Azospirillum canadense sp. nov., a nitrogen-fixing bacterium isolated from corn rhizosphere. Int J Syst Evol Microbiol 57, 620-624.

Mehnaz, S., Weselowski, B. \& Lazarovits, G. (2007b). Azospirillum zeae sp. nov., a diazotrophic bacterium isolated from rhizosphere soil of Zea mays. Int J Syst Evol Microbiol 57, 2805-2809.

Mesbah, M., Premachandran, U. \& Whitman, W. B. (1989). Precise measurement of the $\mathrm{G}+\mathrm{C}$ content of deoxyribonucleic acid by highperformance liquid chromatography. Int J Syst Bacteriol 39, 159-167. 
Minnikin, D. E., O'Donnell, A. G., Goodfellow, M., Alderson, G., Athalye, M., Schaal, K. \& Parlett, J. H. (1984). An integrated procedure for the extraction of bacterial isoprenoid quinones and polar lipids. J Microbiol Methods 2, 233-241.

Murray, R. G. E., Doetsch, R. N. \& Robinow, F. (1994). Determinative and cytological light microscopy. In Methods for General and Molecular Bacteriology, pp. 21-41. Edited by P. Gerhardt, R. G. E. Murray, W. A. Wood \& N. R. Krieg. Washington, DC: American Society for Microbiology.

Okon, Y. \& Itzigsohn, R. (1992). Poly- $\beta$-hydroxybutyrate metabolism in Azospirillum brasilense and the ecological role of PHB in the rhizosphere. FEMS Microbiol Lett 103, 131-139.

Okon, Y. \& Vanderleyden, J. (1997). Root-associated Azospirillum species can stimulate plants. ASM News 63, 366-370.

Patriquin, D. G., Döbereiner, J. \& Jain, D. K. (1983). Sites and processes of association between diazotrophs and grasses. Can $J$ Microbiol 29, 900-915.

Peng, G., Wang, H., Zhang, G., Hou, W., Liu, Y., Wang, E. T. \& Tan, Z. (2006). Azospirillum melinis sp. nov., a group of diazotrophs isolated from tropical molasses grass. Int J Syst Evol Microbiol 56, 1263-1271.

Poly, F., Monrozier, L. J. \& Bally, R. (2001). Improvement in the RFLP procedure for studying the diversity of nifH genes in communities of nitrogen fixers in soil. Res Microbiol 152, 95-103.

Reinhold, B., Hurek, T., Fendrik, I., Pot, B., Gillis, M., Kersters, K., Thielemans, S. \& De Ley, J. (1987). Azospirillum halopraeferens sp. nov., a nitrogen-fixing organism associated with roots of Kallar grass (Leptochloa fusca (L.) Kunth). Int J Syst Bacteriol 37, 43-51.

Saitou, N. \& Nei, M. (1987). The neighbor-joining method: a new method for reconstructing phylogenetic trees. Mol Biol Evol 4, 406425.

Sasser, M. (1990). Identification of bacteria by gas chromatography of cellular fatty acids, MIDI Technical Note 101. Newark, DE: MIDI Inc.

Saxena, B., Modi, M. \& Modi, V. V. (1986). Isolation and characterization of siderophores from Azospirillum lipoferum D-2. J Gen Microbiol 132, 2219-2224.

Seldin, L. \& Dubnau, D. (1985). Deoxyribonucleic acid homology among B. polymyxa, B. macerans, B. azotofixans and other nitrogenfixing Bacillus strains. Int J Syst Bacteriol 35, 151-154.
Seshadri, S., Muthukumarasamy, R., Lakshinarasimhan, C. \& Ignacimuthu, S. (2000). Solubilization of inorganic phosphates by Azospirillum halopraeferans. Curr Sci 79, 565-567.

Stackebrandt, E. \& Goebel, B. M. (1994). Taxonomic note: a place for DNA-DNA reassociation and $16 \mathrm{~S}$ rRNA sequence analysis in the present species definition in bacteriology. Int J Syst Bacteriol 44, 846849.

Steenhoudt, O. \& Vanderleyden, J. (2000). Azospirillum, a free-living nitrogen-fixing bacterium closely associated with grasses: genetic, biochemical and ecological aspects. FEMS Microbiol Rev 24, 487-506.

Tamura, K., Dudley, J., Nei, M. \& Kumar, S. (2007). MEGA4: molecular evolutionary genetics analysis (MEGA) software version 4.0. Mol Biol Evol 24, 1596-1599.

Tarrand, J. J., Krieg, N. R. \& Döbereiner, J. (1978). A taxonomic study of the Spirillum lipoferum group, with descriptions of a new genus, Azospirillum gen. nov. and two species, Azospirillum lipoferum (Beijerinck) comb. nov. and Azospirillum brasilense sp. nov. Can J Microbiol 24, 967-980.

Thompson, J. D., Gibson, T. J., Plewniak, F., Jeanmougin, F. \& Higgins, D. G. (1997). The CLUSTAL_X windows interface: flexible strategies for multiple sequence alignment aided by quality analysis tools. Nucleic Acids Res 25, 4876-4882.

Thuler, D. S., Floh, E. I., Handro, W. \& Barbosa, H. R. (2003). Plant growth regulators and amino acids released by Azospirillum sp. in chemically defined media. Lett Appl Microbiol 37, 174-178.

Tien, T. M., Gaskins, M. H. \& Hubbell, D. H. (1979). Plant growth substances produced by Azospirillum brasilense and their effect on the growth of pearl millet (Pennisetum americanum L.). Appl Environ Microbiol 37, 1016-1024.

Watts, D. \& MacBeath, J. R. (2001). Automated fluorescent DNA sequencing on the ABI PRISM 310 Genetic Analyzer. Methods Mol Biol 167, 153-170.

Xie, C. H. \& Yokota, A. (2005). Azospirillum oryzae sp. nov., a nitrogen-fixing bacterium isolated from the roots of the rice plant Oryza sativa. Int J Syst Evol Microbiol 55, 1435-1438.

Young, C.-C., Hupfer, H., Siering, C., Ho, M.-J., Arun, A. B., Lai, W.-A., Rekha, P. D., Shen, F.-T., Hung, M.-H. \& other authors (2008). Azospirillum rugosum sp. nov., isolated from oil-contaminated soil. Int J Syst Evol Microbiol 58, 959-963. 